\title{
Potential elicitors on secondary metabolite production and antioxidant defence activity of two tomato (Solanum lycopersicum L.) varieties
}

\author{
Alhagie K. Cham, ${ }^{1}$ Ma del Carmen Ojeda Zacarías, ${ }^{1}$ Héctor Lozoya Saldaña, ${ }^{2}$ \\ Rigoberto E. Vázquez Alvarado, ${ }^{1}$ Emilio Olivares Sáenz, ${ }^{1}$ Guillermo C.G. Martínez-Ávila, ${ }^{1}$ \\ Omar Guadalupe Alvarado Gómez ${ }^{1}$ \\ ${ }^{1}$ Faculty of Agronomy, Autonomous University of Nuevo León, Nuevo León; ${ }^{2}$ Phytotechnics Department, \\ Autonomous University of Chapingo, Chapingo, Mexico
}

\begin{abstract}
Highlights
- Elicitors increase the enzymatic activity of PPO in tomato leaves.

- The production of total phenolic contents and flavonoids depends on type of elicitors.

- No effects on the peroxidase content of the tomato leaves.

- The antioxidant capacity of the aqueous fruits extract showed a significant difference $(P=0.05)$ between the treatments in the Saladette variety.

- Positive relationship between total phenolic contents and flavonoids.
\end{abstract}

\begin{abstract}
Plants protect themselves, after pathogen attack, through the passive and active defence mechanisms. The treatment of plants with various agents, including cell wall fragments, plant extracts, and synthetic chemicals, can induce resistance to subsequent pathogen attack both locally and systemically. In view of the capability of phytochemicals compounds found in fruits and vegetables with different proven health benefits to consumers, there are different strategies to enhance the concentration of these compounds, among which the use of elicitors. Elicitation has been used to trigger different defence responses in plants, which lead to different mechanisms, such as activation of enzymes related with secondary metabolism. In this study we investigated the effects of elicitors (Activane ${ }^{\circledR}$, Micobiol $^{\circledR}$, Stemicol ${ }^{\circledR}$ in doses of $1.8 \mathrm{~g} \mathrm{~L}^{-1}$,
\end{abstract}

Correspondence: Ma del Carmen Ojeda Zacarías, Faculty of Agronomy, Autonomous University of Nuevo León, Street Francisco Villa S/N, Col. Ex Hacienda El Canada, Gral. Escobedo, Nuevo León, P.C. 66054, Mexico.

E-mail: maria.ojedazc@uanl.edu.mx ; ojeda.cz@hotmail.com

Key words: Enzymes; flavonoids; fruit; greenhouse; pathogens; phenols.

Acknowledgements: the authors acknowledge the support of the National Council of Science and Technology (CONACyT), Faculty of Agronomy of the Autonomous University of Nuevo Leon (FAUANL) and Lida de México SA DE CV.

Received for publication: 28 March 2021.

Revision received: 7 June 2021.

Accepted for publication: 7 June 2021.

(C) Copyright: the Author(s), 2021

Licensee PAGEPress, Italy

Italian Journal of Agronomy 2021; 16:1883

doi:10.4081/ija.2021.1883

This article is distributed under the terms of the Creative Commons Attribution Noncommercial License (by-nc 4.0) which permits any noncommercial use, distribution, and reproduction in any medium, provided the original author(s) and source are credited.
$3 \mathrm{~m} \mathrm{~L}^{-1}$ and $2.5 \mathrm{~g} \cdot \mathrm{L}^{-1}$ ) on the activity of two enzymes (polyphenoloxydase and peroxidase) in leaves as well as on the bioactive content (DPPH scavenging activity, total phenol and total flavonoid content) in fruits of Solanum lycopersicum L. The elicitors studied affected the production of enzyme and antioxidant activities in tomato, though showed a variable influence on the production of total phenolic and flavonoid content in tomato fruits. In general, the elicitors are able to increase polyphenoloxydase activity in leaves and phytochemical properties in fruits, with a significant negative correlation between the DPPH scavenging activity, total phenolic and flavonoids. These findings provide positive directions for the possible use of these elicitors in tomato ('Bola' and 'Saladette') production in greenhouse.

\section{Introduction}

Tomato is one of the most widely grown fruits worldwide, known for its economic significance and nutritional properties. However, under greenhouse conditions temperature and humidity play a major role in causing various diseases that affect production (FIRA, 2019; SIAP, 2019). Environment-friendly methods of controlling tomato diseases include agroecological practices, organic fungicides, and biological control. Plants' resistance against pathogens is induced by applying agents called elicitors to the plants and would lead to disease prevention or reduced severity as well as increased yield (Sbaihat et al., 2016; García et al., 2018).

It is noteworthy that tomato has been intensively studied due to its high levels of molecules with antioxidant activity (AA), such as carotenoids, phenols, and flavonoids. Indeed, tomato has been named a functional food because some of its phytochemical and bioactive compounds, for example AA, could play protective roles in reducing chronic diseases, such as cancer and cardiovascular disease. These antioxidants also have the ability to protect organisms from damage caused by free radical-induced oxidative stress (Goyal et al., 2010; Moreno-Escamilla et al., 2017).

Previously several elicitors were shown to induce the secondary metabolism and enhance the biosynthesis of many secondary metabolites, It was observed that the abiotic elicitors mainly $\mathrm{CaCl}_{2}(0.5 \%)$ and INA $(2.5 \mathrm{mM})$ have shown a greater induction ability on the production of defence enzymes like PPO, PAL, and 
b-1,3 glucanase, polyphenols and flavonoids in tomato (Chakraborty et al., 2016). Meanwhile, tomato fruit is also rich in bioactive compounds with antioxidant activity, the levels of which can vary over time in response to biotic and abiotic factors, including the application of elicitors (Ávila-Juárez and MirandaRodríguez, 2018; Tumpa and Khokon, 2020).

Presently, the use of elicitors in crop protection and pest management is still in the very early stages of use as a new control method, and thus the current experiences come from experimental trials, and not yet from large scale agricultural use. The following advantages of using elicitor treatments have been reported or can be expected: reduced damage from insects, fungi, pests, and herbivores, reduced environmental hazards. As elicitors affect directly the crop plant, and their acute toxicity to other organisms is lower than that of pesticides, as protective agrochemicals, they can be applied with the current spraying technology, and these treatments could be an alternative to genetically modified (GM) plants for better attraction of natural enemies of pest organisms on cultivated plants (Garcia-Brugger et al., 2006; Thakur and Sohal, 2013). The existence of specific high-affinity binding sites has been demonstrated for oligosaccharide, glycopeptide, and peptide elicitors, and candidate elicitor-binding proteins have been identified for several of them (Fritig and Legrand, 1993; Hahn, 1996). Elicitor nature, doses and time of treatment strongly affects the intensity of the plant response, also can stimulate different classes of secondary metabolites and affect in a different way the concentration of these compounds, being more dependent on plant genetics (species and cultivars) than on the elicitor nature (Baenas et al., 2014).

The objective of the present study was to investigate the effects of several compounds with elicitor properties (Activane ${ }^{\circledR}$, Micobiol $^{\circledR}$ and Stemicol ${ }^{\circledR}$ ), on the production of phytochemical compounds and antioxidant activities in fruits as well as enzyme activities of polyphenoloxydase and peroxidase in the leaves in tomato plants.

\section{Materials and methods}

\section{Plant material and growth conditions}

Tomato (Solanum lycopersicum L.) is an extremely important crop for the economy of several countries like Mexico and thus chosen as the model plant in this study, using two important varieties, 'Bola' and 'Saladette', cultivated in greenhouse conditions. The aforementioned varieties were cultivated under the greenhouse 'Israelita' during the summer-spring 2019-2020 at the Center for Protected Agriculture (CAP) of the Faculty of Agronomy of the Autonomous University of Nuevo León (UANL), located at the Campus of Agricultural Sciences in the municipality of Gral. Escobedo, NL. Subsequently, the analysis of the samples was conducted at the chemistry laboratory of the above mentioned faculty.

\section{Experimental design and treatments}

The efficacy of different elicitors on induction of defence response was assessed by determining the production of enzymes (Peroxidase and Polyphenol Oxidase), antioxidant activity by means of the DPPH test and Total phenolic and flavonoid content in bola and saladette tomato fruits. A completely randomized experimental design with four treatments was used: T1: (Control), T2: $\left(\right.$ Activane $\left.^{\circledR}\right)$, T3: $\left(\right.$ Micobiol $\left.^{\circledR}\right)$, T4: $\left(\right.$ Stemicol $\left.^{\circledR}\right)$ and four repetitions in each one, with a total of 256 plants, where the effect of the elicitors in eight applications at different stages of the crop cycle was evaluated. For each elicitor, the dose recommended and the information about the products by the production company, 'Lida de Mexico' (Table 1) was used.

\section{Enzymatic extract method}

The procedure reported by Casado-Vela et al. (2005) with some modifications was used. $1 \mathrm{~g}$ of the vegetative materials (leaves) was weighed, which were homogenized with $5 \mathrm{~mL}(0.1 \mathrm{M})$ phosphate buffer, $\mathrm{pH}$ 7.0. The extracts obtained were placed in $15 \mathrm{~mL}$ centrifuge tubes and subsequently centrifuged at $5000 \times \mathrm{g}$ for 5 minutes at $4^{\circ} \mathrm{C}$. The supernatants collected were used as the crude enzyme source for the enzymatic assays and placed in $1.5 \mathrm{~mL}$ Eppendorf tubes wrapped in aluminium foil and stored under refrigeration at $-20{ }^{\circ} \mathrm{C}$ until use.

\section{Evaluation of the enzymatic activity of polyphenol oxidase}

The polyphenol-oxidase (PPO) (EC 1.14.18.1 or EC 1.10.3.2) activity was estimated using the method of Gasull and Becerra (2006). The reaction mixture consisted of three tubes: reaction tube, blank enzyme and blank substrate tube with 1000, 1300 and $1200 \mu \mathrm{L}$ of $0.1 \mathrm{M}$ phosphate buffer $(\mathrm{pH} 7.0)$ and $300 \mu \mathrm{L}$ of gallic acid at a concentration of $500 \mathrm{ppm}$ was added to the reaction and blank substrate tubes. Subsequently, the assay mixture was incubated for $2 \mathrm{~min}$ at $40^{\circ} \mathrm{C}$. Reaction was stopped by adding $200 \mu \mathrm{L}$ of enzyme extract to reaction and blank enzyme tubes, and the final assay mixture was incubated at $40^{\circ} \mathrm{C}$ for 1 hour. The absorbance at $420 \mathrm{~nm}$ of the reaction and blank substrate tubes mixtures was used to determine against the blank enzyme mixture, the absorbance measurements were carried out in a UV spectrophotometer. The PPO activity was expressed in units per $\mathrm{g}^{-1}$ of fresh tissue $\left(\mathrm{U} \mathrm{g} \mathrm{g}^{-1} \mathrm{fw}\right)$.

\section{Evaluation of the enzymatic activity of peroxidase}

The peroxidase (PO) activity was estimated following the method of Wititsuwannakul (1997). The assay mix contains $200 \mu \mathrm{L}$ of 2,2'azino-di-(3-ethylbenzthiazoline sulfonic acid) or ABTS in $100 \mu \mathrm{L}$ of hydrogen peroxide $\left(0.1 \mathrm{M} \mathrm{H}_{2} \mathrm{O}_{2}\right)$, in $500 \mu \mathrm{L}$ phosphate buffer, $\mathrm{pH} 7.0$ with $200 \mu \mathrm{L}$ of enzyme extract with total volume of $1000 \mu \mathrm{L}$ or $1 \mathrm{~mL}$. The reaction was incubated for $1 \mathrm{~min}$ and homogenized, and then hydrogen peroxide $\left(\mathrm{H}_{2} \mathrm{O}_{2}\right)$ was added and incubated for $5 \mathrm{~min}$. Finally, peroxidase absorption change was measured at $734 \mathrm{~nm}$ at $30^{\circ} \mathrm{C}$ due to oxidation of ABTS, using the assay mixture, without enzyme, as a blank. One unit of activity was defined as the amount of enzyme necessary to produce a change in absorbance from 0.1 to $734 \mathrm{~nm}$ per min.

\section{Evaluation of DPPH radical scavenging activity}

The antioxidant capacity of DPPH was determined by the methodology cited by Kuskoski et al. (2005). Prepared reagent of the DPPH (2, 2-Diphenyl-1-picrylhdrazyl) was diluted in methanol at a concentration

Table 1. List of the elicitors applied on leaves of the two tomato varieties studied.

\begin{tabular}{lccc} 
Elicitor & Elicitor source & Elicitor properties & Dose applied \\
Activane $^{\circledR}$ & Crustaceans & Chito-oligosaccharides (COS) & $1.8 \mathrm{~g} \mathrm{~L}^{-1}$ \\
& Vegetable Origin & Phenols & $3 \mathrm{~mL} \mathrm{~L}^{-1}$ \\
Micobiol $^{\circledR}$ & Yeast & $\beta$-glucan & $2.5 \mathrm{~g} \mathrm{~L}^{-1}$ \\
\hline Stemicol & ${ }^{\circledR}$ & Crustaceans & Chito-oligosaccharides (COS) \\
\hline
\end{tabular}


of $60 \mu \mathrm{M}$. The test tubes were labelled according to the number of samples to be analyzed and the concentrations of the calibration curve. Then $50 \mu \mathrm{L}$ of each concentration of the calibration curve was pipetted into their corresponding test tubes. Subsequently, $50 \mu \mathrm{L}$ of the sample to be analyzed was pipetted into their corresponding test tubes (considering the dilution factor of the sample) and $2950 \mu \mathrm{L}$ of DPPH reagent was added to both calibration curve and sample tubes to be analyzed. Upon homogenization, they were incubated for 30 minutes at room temperature in the dark. The analysis was performed in triplicate. Finally, the absorbance (Abs) was measured at $517 \mathrm{~nm}$ using a GENESYSTM 40/50 Vis/UV-Vis Spectrophotometers (Thermo Fisher Scientific Inc., Waltham, MA, USA) and the percentage of reduction of DPPH was determined, both for the samples (enzymatic extract), and for the gallic acid dilutions. The stock solution of gallic acid was prepared at a concentration of $200 \mathrm{ppm}$. The ability to scavenge the radical was calculated by the following Equation 1:

Inhibition $(\%)=[($ A control A sample $) / A$ control $] \times 100$

ehere A control is the absorbance of the control reaction (containing all reagents except the test compound) and A sample is the absorbance with the test compound. The antioxidant capacity of DPPH in samples was expressed as mill equivalent of gallic acid per $\mathrm{g}^{-1}$ of fresh tissue $(\mathrm{mEq}$ $\left.\mathrm{GA} \mathrm{g}^{-1} \mathrm{fw}\right)$.

\section{Estimation of total phenolic content}

Total phenolic content was determined using the Folin-Ciocalteu's Reagent. First, a stock solution of gallic acid at a concentration of 200 ppm was prepared and the calibration curve performed. Subsequently, a solution of Sodium Carbonate $\left(\mathrm{Na}_{2} \mathrm{CO}_{3}\right)$ at a concentration of $75 \mathrm{~g} \mathrm{~L}^{-1}$ was prepared, test tubes were labelled according to the number of samples to be analyzed and calibration curve concentrations and $250 \mu \mathrm{L}$ added of each concentration from the calibration curve into their corresponding test tubes Subsequently, $250 \mu \mathrm{L}$ of the sample to be analyzed into their corresponding test tubes (consider the dilution factor of the sample) and add $250 \mu \mathrm{L}$ of Folin-Ciocalteu's Reagent at each concentration of the calibration curve and sample to be analyzed. Then $250 \mu \mathrm{L}$ of the sodium carbonate solution pipetted at each concentration of the calibration curve and sample to be analyzed. Finally, the samples were homogenize and incubate in a water bath for 30 minutes at $40^{\circ} \mathrm{C}$. then 2 $\mathrm{mL}$ of distilled $\mathrm{H}_{2} \mathrm{O}$ added to each concentration of the calibration curve and sample to be analyzed to be read at absorbance at $750 \mathrm{~nm}$ using a UV spectrophotometer. Total phenolic content in samples was expressed as milligrams per millilitre of gallic acid equivalents $\mathrm{g}^{-1}$ of fresh tissue (mg GAE $\mathrm{g}^{-1} \mathrm{fw}$ ).

\section{Estimation of total flavonoid content}

Total flavonoid content was determined by adapting the method of De la Rosa et al. (2014), with some modifications. First of all, prepare a stock solution of quercetin at a concentration of $1000 \mathrm{ppm}$ and perform the calibration curve. Subsequently, prepare a solution of Sodium Nitrite $\left(\mathrm{NaNO}_{2}\right)$ at a concentration of $5 \%$, solution of aluminium chloride $\left(\mathrm{AlCl}_{3}\right)$ at a concentration of $10 \%$ and a solution of sodium hydroxide $(\mathrm{NaOH})$ at a concentration of $1 \mathrm{M}$. Then label test tubes according to the number of samples to be analyzed and calibration curve concentrations. Proceed by pipetting $150 \mu \mathrm{L}$ of each concentration from the calibration curve into their corresponding test tubes and pipette $150 \mu \mathrm{L}$ of the sample to be analyzed into their corresponding test tubes (consider the dilution factor of the sample). Add $150 \mu \mathrm{L}$ of the sodium nitrite solution at each concentration of the calibration curve and sample to be analyzed and $150 \mu \mathrm{L}$ of the aluminium chloride solution at each concentration of the calibration curve and sample to be analyzed. Finally, add $1 \mathrm{~mL}$ of the sodium hydroxide solution at each concentration of the calibration curve and sample to be analyzed. Homogenize and read absorbance at $510 \mathrm{~nm}$ using a UV spectrophotometer (thermo-electron). The amount of total flavonoid was expressed as $\mathrm{mg} / \mathrm{mL}$ quercetin $\mathrm{g}^{-1}$ of fresh tissue (mg QE $\left.\mathrm{g}^{-1} \mathrm{fw}\right)$.

\section{Statistical analysis}

Statistical analyses were performed using SPSS STATISTIC software version 21.0 (IBM 2015), program for Windows. The data were analysed separately for each experiment and means were compared using student's t-test, and differences were compared through Tukey's test at $\mathrm{P}=0.05$.

\section{Results and discussion}

\section{The effect of elicitors on enzymatic activity of polyphe- nol oxidase}

The enzymatic tests of PPO activity carried out on the leaves of Bola and Saladette varieties show that the PPO activity was higher in the treatments with elicitors during the crop growing season, with a significant difference $(\mathrm{P}=0.05)$ for the two varieties of tomatoes evaluated. The differences in the results obtained can be attributed to the effect of the application of the elicitors during the crop cycle (Figure 1).

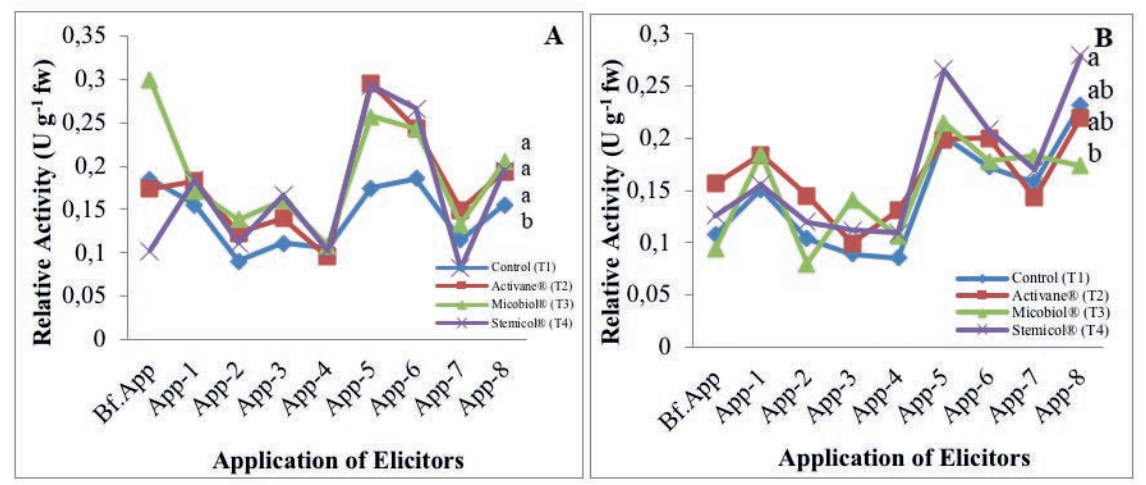

Figure 1. Enzymatic activity of PPO in the leaves during the summer-spring 2019-2020 growing season of the bola (A) and saladette (B) tomato varieties. Values associated to different letters are significantly different $(P=0.05)$ according to Tukey's multiple range test. 
The high PPO activity during the growth and development of the two tomato varieties with the applications of the elicitors demonstrate the capacity of the elicitors in increasing the PPO activity in the tomato crop and in protecting against pathogens. The knowledge of PPOs in vegetables is a fundamental step in the investigation, since it will allow improving the quality and appearance of fresh and processed fruits and vegetables, reducing the economic losses that its effect in the agri-food industry supposes. According to Mayorga and Higuera (2007), polyphenol oxidase is a copper-dependent oxide-reductase that catalyses the reaction between catechol and oxygen to give benzoquinone and other quinones, products that interact with other molecules forming, among others, coloured compounds responsible for plant browning. Furthermore, these oxidases may be involved with the production of phenolic compounds, precursors of lignin synthesis for the reinforcement of plant walls, a process that plays an important role in the defence responses of plants. In addition, Thakur and Sohal (2013) reported elicitors as compounds which activate chemical defence in plants. Also, various biosynthetic pathways are activated in treated plants depending on the compound used. Commonly tested chemical elicitors are salicylic acid, methyl salicylate, benzothiadiazide, benzoic acid, chitosan, and so forth which affect production of phenolic compounds and activation of various defence-related enzymes in plants. Their introduction into agricultural practice could minimize the scope of chemical control, thus contributing to the development of sustainable agriculture. The results suggest direct involvement of abiogenic elicitors like dipotassium hydrogen orthophosphate $\left(\mathrm{K}_{2} \mathrm{HPO}_{4}\right)$, oxalic acid (OA), isonicotinic acid (INA), salicylic acid (SA), acetylsalicylate (AS), arachidonic acid (AA) and calcium chloride $\left(\mathrm{CaCl}_{2}\right)$ to stimulate innate immune responses in Lycopersicum esculentum Mill.. Excised tomato leaves, treated with elicitors at three different concentrations, were found to stimulate defence and antioxidative enzymes after $24 \mathrm{~h}$ of incubation. $\mathrm{CaCl}_{2}(0.5 \%)$ followed by INA $(2.5 \mathrm{mM})$ were found most effective in activation of all such defence molecules in tomato leaves (Chakraborty et al., 2016). Mandal et al. (2013) had shown that the elicitors SA and CHT induced effective defence responses in tomato plants against Ralstonia solanacearum. The reduced disease incidence in tomato by SA and CHT may be a result of cell wall strengthening through deposition of lignin and induction of defence enzymes.

\section{The effect of elicitors on enzymatic activity of peroxi- dase}

Based on the results obtained and under the conditions in which the work was carried out, the application of elicitors (Activane $^{\circledR}$, Micobiol ${ }^{\circledR}$ and Stemicol ${ }^{\circledR}$ ) on the leaves of the two tomato varieties showed no effects on the peroxidase content of the plant evaluated. The results obtained suggest that peroxidase constitutes one of the defence mechanisms of the tomato plant that is shown to express upon mechanical wounding and against the attack of pathogens. According to various investigations, peroxidases have been reported to be induced by infections caused by fungi, bacteria, viruses and viroids, etc. They also reported that, among the proteins induced during plant defence, plant peroxidases are well known and play a role through: reinforcing physical cell wall barriers comprising lignin, suberin, feruloylated polysaccharides, and hydroxyproline-rich glycoproteins. Peroxidases have also been reported to be induced by fungal infections and a rapid induction of a cationic peroxidase has been reported in rice plants infected with Xanthomonas oryzae pv. Oryzae (Reimers et al., 1992). On the other hand, Pandey et al. (2017) reported that plants respond to wounding by activating self-defence systems to restore damaged tissues or to defend against attacks by pathogens and herbivores. Among the large number of wound-inducible proteins, peroxidase have been shown to express upon mechanical wounding in various plants, including tobacco, tomato, potato, cucumber, azuki bean, rice, horseradish and sweet potato.

\section{The effect of elicitors on DPPH radical scavenging activity}

In the present study, the antioxidant activity of the extracts from the fruits was estimated using the DPPH scavenging assay, reducing power of the extract and by determining the total antioxidant capacity of the extract. All these have proven the effectiveness of the methanol fruit extract of the two varieties of tomato compared with the reference standard. The DPPH antiox-
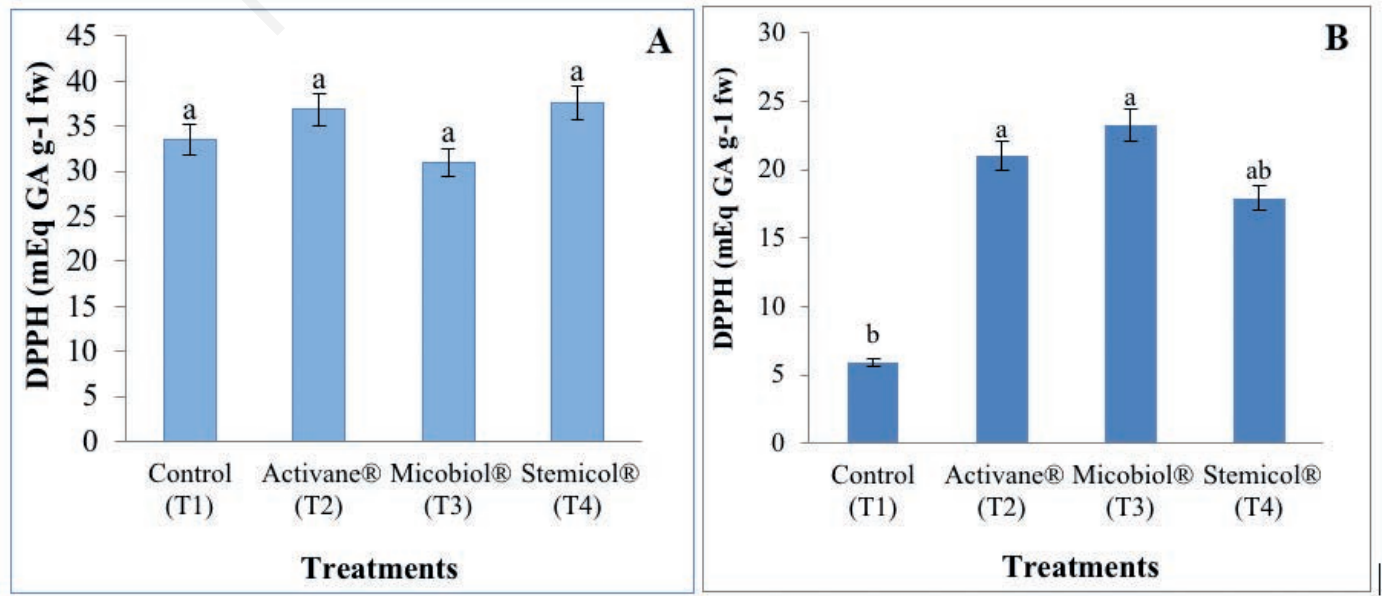

Figure 2. Effect of the application of elicitors on antioxidant activity of the DPPH scavenging activity in tomato fruits of 'Bola' (A) and 'Saladette' $(B)$. Values associated to different letters are significantly different $(P=0.05)$ according to Tukey's multiple range test. 
idant assay is based on the ability of DPPH, a stable free radical, to decolorize in the presence of antioxidants. The antioxidant capacity of the aqueous fruits extract showed a significant difference $(\mathrm{P} \leq 0.05)$ between the treatments in the Saladette variety (Figure 2). The production of the tomato crop under greenhouse condition through the applications of the elicitors in the present study showed a significant effect on the 2-2-diphenyl-1-picrylhydrazyl radicals (DPPH) activity with respect to the Control (T1), and showed a significant differences $(\mathrm{P}=0.05)$ according to the $\mathrm{DPPH}$ test in the Saladette variety. The same test with the Bola variety did not show any significant differences $(\mathrm{P}=0.05)$ among the treatments evaluated. The treatments with the elicitors that were tested in the present work reflected their effect on the content of the compounds responsible for the antioxidant activity of tomato fruits. Activane ${ }^{\circledR}$ and Micobiol ${ }^{\circledR}$ elicitors were the most suitable for obtaining high antioxidant activity in tomato fruits in this work, though capable of trapping reactive oxygen species, reducing oxidative stress and reducing the danger of oxidation of cellular components. These results are consistent with those of Ávila-Juárez and Miranda-Rodríguez (2018), who indicated that certain bioactive compounds and their antioxidant activities varied not only between trusses but also based on the specific elicitor used and their variations in bioactive content in different tomato trusses due to elicitor effects. On the other hand, according to Pandey et al. (2017), enzyme and antioxidant activity was found highest at various concentrations of the elicitor treatment. However, AA activity was elevated with the increasing doses of elicitors. This finding suggests that the AA should increase with the flavonoid content in the fruit as demonstrated in this study because the AA is mainly influenced by hydrophilic antioxidants $(83 \%)$, such as phenolics.

\section{The effect of elicitors on the total phenolic content}

The elicitors showed a variable influence on the production of total phenolic content in fruit of the two tomato varieties. It is clear from Figure $3 \mathrm{~A}$ and $\mathrm{B}$ that among the elicitors, Activane ${ }^{\circledR}$ and Micobiol ${ }^{\circledR}$ had greater potential to significantly amplify the production of total phenolics content, and both the elicitor showed the highest total phenolic content compared to control.
Although the differences between total phenolic content in tomato fruits, regarding the greenhouse environmental conditions, were not statistically significant, the increase in total phenolic content in greenhouse tomato fruits could be a plant response to the application of the elicitors.

Phenolic compounds may contribute directly to the antioxidative action. The highest total phenolic content in both varieties were recorded for the elicitors Activane ${ }^{\circledR}$ and Micobiol ${ }^{\circledR}$ 105.465, 102.598 and $102.2,100.305 \mathrm{mg} / \mathrm{mL}$, gallic acid equivalent per $\mathrm{g}$ fresh tissue. Results from this study were superior to that of Perea-Domínguez et al. (2018) where phenolic composition was determined using Folin-Ciocalteu's method and showed predominant in grape and Saladette tomato extracts $(91.47 \pm 17.28 \mathrm{mg}$ gallic acid equivalents (GAE) per g dry extract (DE) and $57.41 \pm 8.80 \mathrm{mg}$ GAE per g DE, respectively). In a similar experiment, Peschel et al. (2006) observed a total phenolic content of $61 \mathrm{mg} \mathrm{GAE} / \mathrm{g}$ dry extract in tomato peels. Other results suggest direct involvement of abiogenic elicitors, $\mathrm{CaCl}_{2}$ at a concentration $0.5 \%$ and INA $(2.5 \mathrm{mM})$ have shown a greater potential to significantly amplify the production of phenol with both elicitors to have showed increase in total phenol content compared to control respectively. Similar studies on basil (Hawrylak-Nowak et al., 2021) showed that elicitation of basil with $500 \mathrm{mg} / \mathrm{L}$ of chitosan lactate increased the shoot biomass. Therefore, such an elicitor as chitosal lactate can enhance the accumulation of valuable phytochemicals in this plant. Considering phenolic content as a key component of plant's natural defence, their elevated content in excised tomato due to treatment of various abiotic elicitors may confer the enhancement of resistance to the plant attack against various pathogens. According to Vasconsuelo and Boland (2007), the concentration of elicitors and interval between treatments induce different responses characteristic of plant species, making necessary to find the adequate effective dose and time empirically.

\section{The effect of elicitors on the total flavonoid content}

Results obtained with respect to the total flavonoid content in fruit of the two tomato varieties showed significant difference (Tukey, $\mathrm{P}=0.05$ ) for the Saladette variety. For both varieties, the
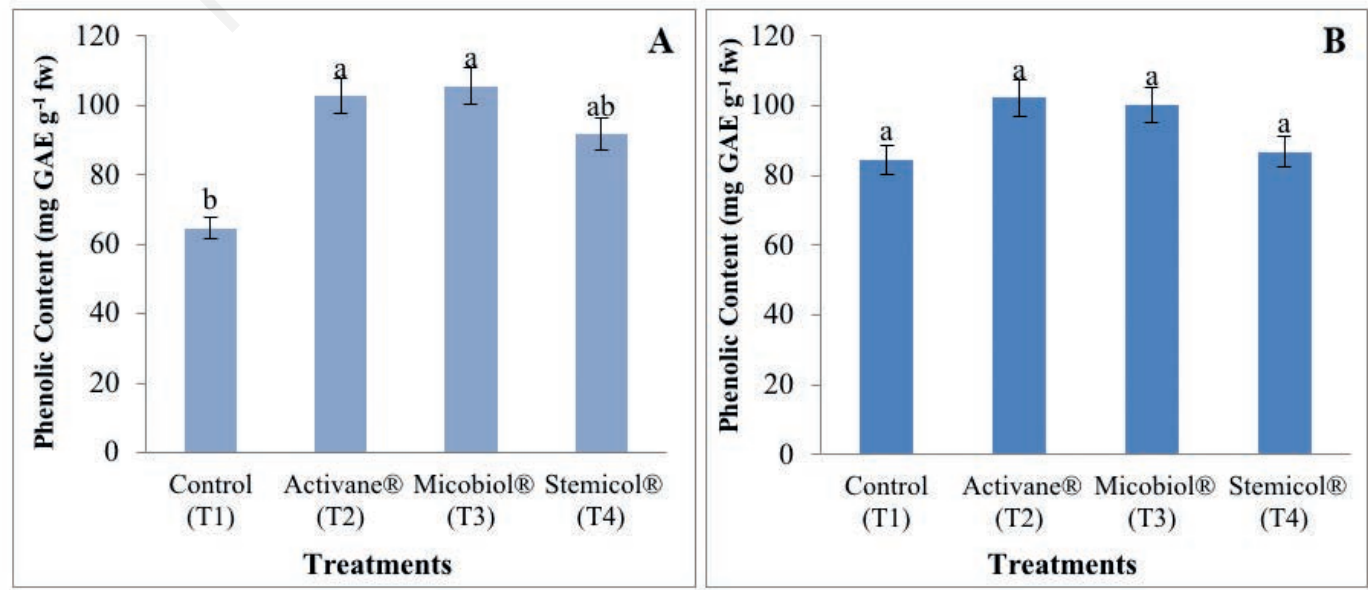

Figure 3. Effect of elicitors on the total phenolic content in tomato fruits of 'Bola' (A) and 'Saladette' (B). Values associated to different letters are significantly different $(P=0.05)$ according to Tukey's multiple range test. 
lowest value of total flavonoid content was found in the treatment Control (T1) with values of 3.793 and $4.15 \mathrm{mg} / \mathrm{mL}$ quercetin equivalent per $\mathrm{g}$ of fresh tissue (Figure 4).

Elicitors (Activane ${ }^{\circledR}$, Micobiol $^{\circledR}$ and Stemicol ${ }^{\circledR}$ ) showed a variable influence on the production of total flavonoid content in tomato fruits. Among all the elicitors, Activane at a concentration of $1.8 \mathrm{~g} \mathrm{~L}^{-1}$ have slight potential to amplify the production of flavonoid content in Bola variety, On the other hand, the elicitor Stemicol ${ }^{\circledR}$ at a concentration of $2.5 \mathrm{~g} \cdot \mathrm{L}^{-1}$ had slight potential to amplify the production of flavonoid content in Saladette variety. However, the values showed elevated level of flavonoid content in fruits of the two tomato varieties due to treatment of the elicitors. These results coincide with the findings of Chakraborty et al. (2016) who after evaluating the effect of abiogenic elicitors on the tomato crop found that elicitors $\mathrm{CaCl}_{2}$ at a concentration $0.5 \%$ and INA $(2.5 \mathrm{mM})$ have shown a greater potential to significantly amplify the production of flavonoid of which both the elicitor showed increase in total flavonoid content compared to control respectively. In contrast, compared to other sets treated with $\mathrm{K}_{2} \mathrm{HPO}_{4}(2 \mathrm{mM})$ showed least amount of total flavonoid production.

Additionally, Gadzovska et al. (2013, 2014) have already reported that the levels of total phenolic and flavonoid content were unchanged or decreased upon treatment with salicylic acid $(50-250 \mu \mathrm{M})$ as an elicitor. While the study of polysaccharide elicitors such as chitin, pectin, and dextran on the production of phenylpropanoids (phenolics and flavonoids) led to a significant suppression of the production of total phenolics and flavonoids in elicited shoots from day 14 to day 21 of postelicitation. PérezBalibrea et al. (2011) had shown that during MeJA elicitation, applied daily by exogenous spraying at $10 \mu \mathrm{M}$, resulted in a $31 \%$, $23 \%$ and $22 \%$ increase of total flavonoid, phenolic and glucosinolates concentration, respectively, in 7 day old broccoli sprouts. Also, a MeJA sprayed treatment $(10 \mathrm{mM})$ at the beginning of veraison in grape (Vitis vinifera L.) increased anthocyanin and flavanols content up to $81 \%$ and $131 \%$, respectively (Ruiz-García et al., 2012). Meanwhile, SA and jasmonates [jasmonic acids (JA), methyl jasmonate (MeJA)] are widely known to elicit a wide range of compounds by inducing the expression of plant genes for various biosynthetic pathways (Rohwer and Erwin, 2008). Also RuizGarcía and Gómez-Plaza (2013) reported that the use of elicitors may be regarded as a simple and useful technique to increase the phenolic content of fruit, and protect at the same time both plants and fruits from biotic and abiotic stresses. In addition, the elicitors have no environmental impact and risk of creating resistant pathogen strains, which may result from using conventional herbicides and antifungal or antimicrobial compounds.

\section{Correlation between DPPH scavenging activity, total phenol and total flavonoid content}

To determine the relationship between the antioxidant capacity and the content of phenolic compounds and total flavonoids, a Pearson correlation was performed (Table 2). The correlation analysis between total phenolic and flavonoids resulted in a significant linear relationship $(\mathrm{P}=0.012)$, with a coefficient of $r=0.439$, which
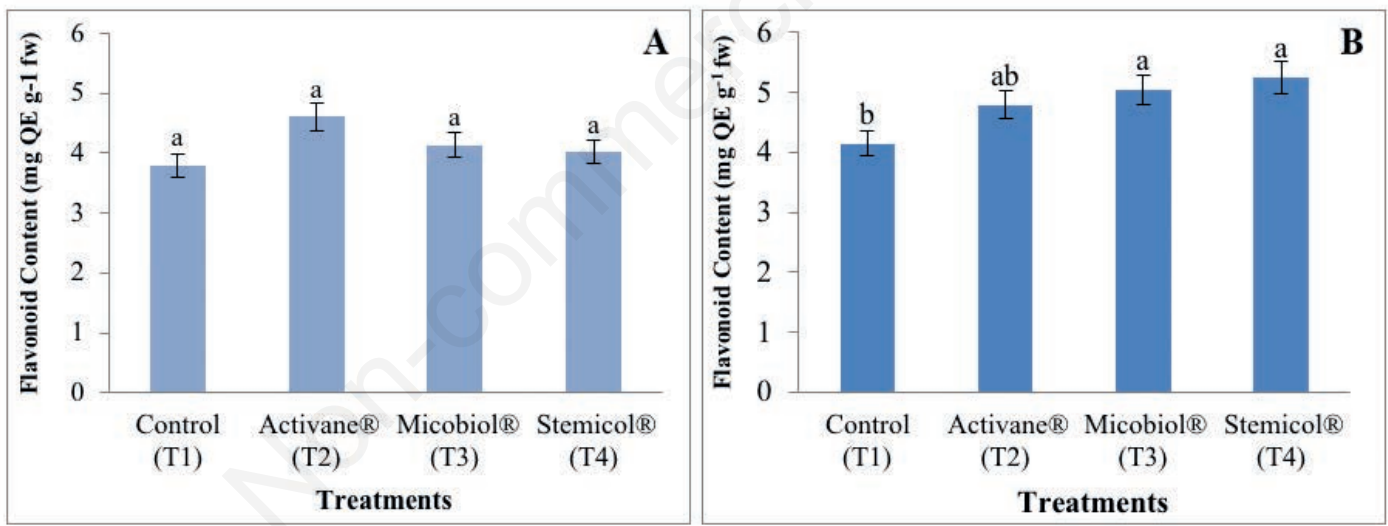

Figure 4. Effect of elicitors on the total flavonoid content in 'Bola' (A) and 'Saladette' (B) tomato fruits. Values associated to different letters are significantly different $(P=0.05)$ according to Tukey's multiple range test.

Table 2. Pearson correlation coefficients between DPPH scavenging activity, total phenol and flavonoid content.

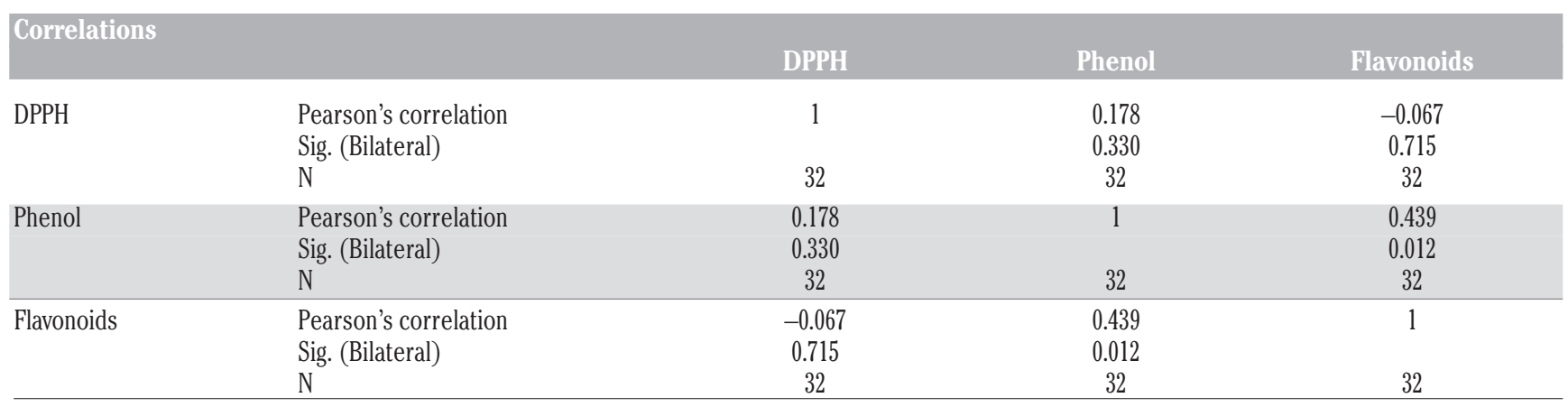


indicates that high values of flavonoids are associated with high values of phenolic content. Differently, the correlations between DPPH and flavonoids, and DPPH and phenolic were not significant respectively. These results agree with the literature pointing to a significant correlation between the percentage of the total phenols and flavonoids as effect of two elicitors, methyl jasmonate (20 $\mu \mathrm{M}$ MeJA) and sodium nitroprusside (500 $\mu \mathrm{M}$ SNP) studied on the six soybean genotypes (Mohamed et al., 2021).

Overall, these correlations confirm the positive relationship between phenolic compounds of phenolic and flavonoids. Similar results obtained by Salas-Pérez et al. (2018) showed that there is a strong positive correlation between antioxidant capacity and phenolic compounds and flavonoids $\left(r^{2}=0.86\right.$ and $\left.r^{2}=0.78\right)$ after citric acid application, which suggests that these compounds are antioxidants in nature. Gorni et al. (2020) found a direct correlation between total phenolic levels and antioxidant activity which was high for DPPH $\left(r^{2}=-0.72\right)$, as well as a high correlation between TFC $\left(r^{2}=0.97\right)$ and ANT $\left(r^{2}=0.67\right)$. Previous studies by Kainama $e t$ al. (2020) also showed high positive correlation between total flavonoid content and ABTS radical scavenging activity for methanol extract and then ethyl acetate had correlation between total flavonoid content. The highest positive relationship in both assays $(r=0.762, \mathrm{P} \leq 0.05)$ for antioxidant activity. These results suggest that $G$. lasoar stem bark extracts can be used as a natural source of antioxidants.

\section{Conclusions}

The application of elicitors in tomato plants did have significant effects on leave enzyme activity and fruit quality. Stemicol ${ }^{\circledR}$ is worth recommending because it demonstrated the capacity to increase the PPO activity in the tomato leaves. The increased content of secondary metabolites and antioxidants responsible for plant defence can enhance their protection against pathogens. On the other hand, Activane ${ }^{\circledR}$ and Micobiol ${ }^{\circledR}$ showed significant effects on the antioxidant activity, total flavonoid and phenolic content in tomato fruits. A significant positive correlation was recorded between total phenolic and flavonoids. Our results suggest both the increase in enzyme activity in leaves, and of antioxidant activity, total flavonoid and phenolic content in tomato fruits, as a consequence of elicitor application.

\section{References}

Ávila-Juárez L, Miranda-Rodríguez H, 2018. Variations in bioactive content in different tomato trusses due to elicitor effects. J. Chem. (Hindawi), 1-9.

Baenas N, García C, Moreno DA, 2014. Elicitation: a tool for enriching the bioactive composition of foods. Mol. 19:13541-63.

Chakraborty N, Ghosh S, Chandra S, Sengupta S, Acharya K, 2016. Abiotic elicitors mediated elicitation of innate immunity in tomato: an ex vivo comparison. Physiol. Mol. Biol. Plants. 22:307-20.

De la Rosa LA, Floresa AV, Parrilla E, Garcia J, Campos ON, Nava A, Reyes S, Chaverri JP, 2014. Content of major classes of polyphenolic compounds, antioxidant, antiproliferative, and cell protective activity of pecan crude extracts and their fractions. J. Funct. Foods. 7:219-28.

FIRA (Trusts Established in Relation to Agriculture), 2019. Red tomato agri-food panorama. Available from: diees@fira.gob.mx

Fritig B, Legrand M, 1993. Mechanisms of plant defence responses. In Fritig B, Legrand M (Eds.), Developments in plant pathology. Springer, Dordrecht, 2:0929-1318

Gadzovska S, Maury S, Delaunay A, Spasenoski M, Hagège D, Courtois D, Joseph C, 2013. The influence of salicylic acid elicitation of shoots, callus, and cell suspension cultures on production of naphtodianthrones and phenylpropanoids in Hypericum perforatum L. Plant Cell Tissue Organ Cult. 113:25-39.

Gadzovska S, Tusevski O, Maury S, Delaunay A, Joseph C, Hagège D, 2014. Effects of polysaccharide elicitors on secondary metabolite production and antioxidant response in Hypericum perforatum L. shoot cultures. Sci. World J. 10:609-49.

García E, Robledo A, Mendoza B, Solís G, González SM, 2018. Efecto de elicitores de origen natural sobre plantas de tomate sometidas a estrés biótico. Rev. Mex. Cienc. Agríc. 9:20.

Garcia-Brugger A, Lamotte O, Vandelle E, Bourque S, Lecourieux D, Poinssot B, Wendehenne D, Pugin A, 2006. Early Signalling Events Induced by Elicitors of Plant Defenses. MPMI. 19:7.

Gorni PH, Pacheco AC, Lima MA, 2020. Elicitation improves the leaf area, enzymatic activities, antioxidant activity and content of secondary metabolites in Achillea millefolium L. grown in the field. J. Plant Growth Regul. 09:23.

Goya AK, Middha SK, Sen A, 2010. Evaluation of the DPPH radical scavenging activity, total phenols and antioxidant activities in Indian wild Bambusa vulgaris 'Vittata' methanolic leaf extract. J. Nat. Pharm.1:2229-5119.

Hahn MG, 1996. Microbial elicitors and their receptors in plants. Annu. Rev. Phytopathol. 34:387-412.

Hawrylak-Nowak B, Dresler S, Rubinowska K, Matraszek-Gawron R, 2021. Eliciting effect of foliar application of chitosan lactate on the phytochemical properties of Ocimum basilicum L. and Melissa officinalis L. Food Chem. 342:128-358.

Kainama H, Fatmawati S, Santoso M, Ersam T, 2020. The relationship of free radical scavenging and total phenolic and flavonoid contents of Garcinia lasoar PAM. Pharm. Chem. J. 53:1151-7.

Mandal S, Kar I, Mukherjee KA, Acharya P, 2013. Elicitorinduced defence responses in Solanum lycopersicum against Ralstonia solanacearum. Sci. World J. 561056:1-9.

Mohamed HI, Mohammed AH, Mohamed NM, Ashry NA, Zaky LM, Mogazy AM, 2021. Comparative effectiveness of potential elicitors of soybean plant resistance against spodoptera littoralis and their effects on secondary metabolites and antioxidant defense system. Gesunde Pflanzen, pp. 1-13.

Moreno-Escamilla JO, Alvarez-Parrilla E, Rosa LA, NúñezGastélum JA, González-Aguilar GA, \& Rodrigo-García J, 2017. Effect of different elicitors and preharvest day application on the content of phytochemicals and antioxidant activity of butterhead lettuce (Lactuca sativa var. capitata) produced under hydroponic conditions. J. Agric. Food Chem. 65:26.

Pandey VP, Awasthi M, Singh S, Tiwari S, Dwivedi UN, 2017. A comprehensive review on function and application of plant peroxidases. Biochem. Anal. Biochem. 6:308.

Perea-Domínguez XP, Hernández-Gastelum LZ, Olivas-Olguin HR, Espinosa-Alonso LG, Valdez-Morales M, Medina-Godoy S, 2018. Phenolic composition of tomato varieties and an industrial tomato by-product: free, conjugated and bound phenolics and antioxidant activity. J. Food Sci. Technol. 55:9.

Pérez-Balibrea S, Moreno DA, García-Viguera C, 2011. Improving 
the phytochemical composition of broccoli sprouts by elicitation. Food Chem. 129:35-44.

Peschel W, Sánchez-Rabaneda F, Diekmann W, 2006. An industrial approach in the search of natural antioxidants from vegetable and fruit wastes. Food Chem. 97:1.

Reimers PJ, Guo A, Leach JE, 1992. Increased activity of a cationic peroxidase associated with an incompatible interaction between Xanthomonas oryzae pv oryzae and rice (Oryza sativa). Plant Physiol. 99:1044-50.

Rohwer CL, Erwin JE, 2008. Horticultural applications of jasmonates: a review. J. Hortic. Sci. Biotechnol. 83:283-304.

Ruiz-García Y, Gómez-Plaza E, 2013. Elicitors: a tool for improving fruit phenolic content. Agriculture. 3:1.

Ruiz-García Y, Romero-Cascales I, Gil-Muñoz R, FernándezFernández JI, López-Roca JM, Gómez-Plaza E, 2012. Improving grape phenolic content and wine chromatic characteristics through the use of two different elicitors: Methyl jasmonate versus benzothiadiazole. J. Agric. Food Chem. 60:1283-90.

Salas-Pérez L, Gaucín-Delgado J, Preciado-Range P, Gonzales-
Fuentes J, Ayala-Garay A, Segura-Castruita M, 2018. La aplicación de ácido cítrico incrementa la calidad y capacidad antioxidante de germinados de lenteja. Rev. Mex. Cienc. Agríc. 20:1.

Sbaihat L, Takeyama K, Koga T, Takemoto D, Kawakita K, 2015. Induced resistance in solanum lycopersicum by algal elicitor extracted from Sargassum fusiforme. Sci. World J. 870520:9 .

SIAP (Agri-Food and Fisheries Information Service), 2019. Available from: https:/www.gob.mx/siap/acciones-y-programas/produccionagricola-33119

Thakur M, Sohal BS, 2013. Role of elicitors in inducing resistance in plants against pathogen infection. Biochemistry 762412.

Tumpa FH, Khokon MAR, 2020. Foliar application of chitosan and yeast elicitor facilitate reducing incidence and severity of Alternaria leaf blight of tomato and brinjal. Res J Plant Pathol. $3: 2-4$.

Vasconsuelo A, Boland R, 2007. Molecular aspects of the early stages of elicitation of secondary metabolites in plants. Plant Sci. 172:861-75. 